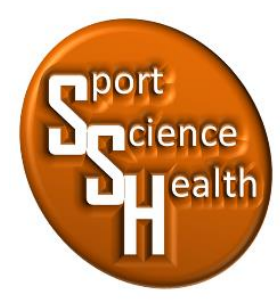

ISSN 2715-3886

\title{
Survei Kondisi Fisik Atlet Pusat Pelatihan Muaythai
}

\author{
Ajeng Suko Wicaksono ${ }^{1 *}$, Eko Hariyanto ${ }^{2}$ \\ 1,2Jurusan Pendidikan Jasmani, Kesehatan dan Rekreasi, Fakultas IImu Keolahragaan, \\ Universitas Negeri Malang, Jalan Semarang No 5, Malang, Jawa Timur, 65145, Indonesia \\ *Penulis koresponden: ajengwicaksono21305@gmail.com, 089618204499
}

Artikel diterima: 3 Januari 2020; direvisi: 16 Februari 2021; disetujui: 22 Februari 2021

\begin{abstract}
This study aims to determine the level of physical condition of muaythai athletes at the training center of Malang Regency. Using a quantitative descriptive design. The instrument in this study used a physical condition skill test. The type of test used was a test of strength, muscle explosive power, speed, and vo2max endurance. The results of the research on the physical condition of Muaythai athletes in the training center of Malang Regency: (1) Abdominal Muscle Strength in the male category on average $50 \%$ less, while the female category is average $62 \%$ (2) Arm muscle strength in the male category is $57 \%$ less while the category female on average $100 \%$ less (3) Explosive Power of leg muscles in the male category on average $33 \%$ less while the female category is average $17 \%$ (4) the 30 sprint category for the male category is average $67 \%$ while the female category is average moderate $67 \%$ (5) The average vo2max endurance of the boys was $33 \%$ less, while the female category was $17 \%$ on average.
\end{abstract}

Keyword: physical condition, athlete, muaythai

Abstrak: Penelitian ini bertujuan untuk mengetahui tingkat kondisi fisik pada atlet muaythai pusat pelatihan Kabupaten Malang. Mengunakan rancangan deskriptif kuantitatif. Instrumen dalam penelitian ini mengunakan tes keterampilan kondisi fisik, Jenis tes yang digunakan tes kekuatan, daya ledak otot, kecepatan, dan daya tahan vo2max. Hasil penelitian kondisi fisik atlet Muaythai pusat pelatihan Kabupaten Malang: (1) Kekuatan Otot Perut kategori putra rata-rata 50\% kurang sedangkan kategori putri rata-rata sedang $62 \%$ (2) Kekuatan Otot Lengan kategori putra rata-rata 57\% kurang sedangkan kategori putri rata-rata kurang $100 \%$ (3) Daya Ledak Otot tungkai kategori putra rata-rata 33\% kurang sedangkan kategori putri rata-rata sedang 17\% (4) sprint 30 kategori putra ratarata sedang $67 \%$ sedangkan kategori putri rata-rata sedang $67 \%$ (5) Daya tahan vo2max putra rata-rata $33 \%$ kurang sedangkan kategori putri rata-rata sedang $17 \%$.

Kata kunci: kondisi fisik, atlet, muaythai

\section{PENDAHULUAN}

Bela diri adalah memperkuat nulari manusia untuk membela diri terhadap serangan lawan maupun dari acaman bahaya (Hollander, 2014; Wang et al., 2019). Setiap cabang olahraga mempunyai karakteristik yang berbeda-beda sebagai ciri khusus dari cabang olahraga itu sendiri, salah satunya cabang olahraga seni bela diri (Alim, 2015; Alit Arsani, 2014; Helen, Oktia, \& Taufiq, 2017). Banyak sekali macam-macam bela diri yang ada di Indonesia salah satunya seni bela diri dari Negara Thailand yang saat ini banyak digemari oleh berbagai kalangan usia, baik digunakan untuk menjaga kebugaran jasmani maupun sebagai ajang mencari prestasi yaitu bela diri muaythai. Muaythai merupakan olahraga pertarungan yang sangat keras, pada pertandingan 
bela diri muaythai menggunakan gabungan teknik serangan dari pukulan tinju, siku, lutut, tulang kerung dan kaki (Kumartasli \& Baştuğ, 2010; Phanpheng, Larha, \& Hirantrakul, 2020; Syarifoeddin, 2018). Dalam bela diri muaythai atlet diwajibkan mempunyai kondisi fisik yang baik atau prima karena selama bertanding atlet muaythai harus menghadapi benturan keras (body contact) langsung dengan lawan. Namun, kenyatan yang terjadi saat ini beberapa atlet muaythai mempunyai kondisi yang kurang baik pada saat melakukan latihan, sparing partner, terlihat sering mengalami kelelahan dangan banyak melakukan istirahat, dan ketika bertanding pada ahir bertanding sering mengalami kelelahan sehingga pencapai prestasi yang didapat tidak maksimal. Kemungkinan kelelahan yang dialami atlet karena pelatih belum memantau secara benar tentang kondisi fisik atletnya dan atlet muaythai pusat pelatihan Kabupaten Malang belum disiplin dalam menjalankan program latihan yang telah dibuat, serta belum ada data-data tentang kondisi fisik atlet muaythai Kabupaten. Atlet yang melakukan program latihan kondisi fisik secara intensif, akan memiliki kekuatan, dan daya tahan yang lebih baik dibandingkan dengan atlet yang memulai program kondisinya hanya 1-2 minggu saja sebelum permulaan musim latihan, yang tujuannya agar kondisi fisik atlet tetap dapat dipertahankan secara baik (Peachey, Damon, Zhou, \& Burton, 2015). Selain dari hasil data di atas, bukti kurangnya kondisi fisik juga disebabkan oleh beberapa faktor dari dalam (Internal) maupun luar (eksternal) dari diri seorang atlet tersebut. Berikut faktor-faktor yang mempengaruhi kondisi fisik yaitu: (1) keturunan, berkaitan dengan faktor biologis, (2) kematangan, semakin matang kondisi atlet semakin mampu menerima beban latihan yang tinggi, (3) gizi, gizi sangat penting bagi perkembangan atlet, (4) waktu istirahat yang teratur, (5) kebugaran, (6) lingkungan, lingkungan dapat berupa lingkungan fisik dan psikis, (7) motivasi yang tinggi dapat meningkatkan kemampuan atlet (Aidar et al., 2018; Moraes et al., 2019). Dari permasalahan tersebut perlu dilakukan kajian terkait "Tingkat Kondisi Fisik Atlet Muaythai Pusat Pelatihan Kabupaten Malang".

\section{Muaythai}

Menurut Cordoza (2006:2) artinya pada ribuan tahun yang lalu, tentara Thailand yang berjuang untuk mempertahankan tanah mereka dari penjajah sehingga menciptakan seni bela diri yang menggunakan teknik serangan tangan, kaki, siku, dan lutut mereka menjadikan senjata yang mematikan (Chinnasee et al., 2018; Phosawat Saengsawang, Chairit Siladech, \& Prapat Laxanaphisuth, 2015). Muaythai atau tinju thai adalah seni bela diri keras dari kerajaan thai dari Negara Tahiland sekilas muaythai dan kickboxing memiliki teknik pertarungan yang hampir sama, yang membedakan adalah teknik bertarung muaythai boleh menggunakan sikuan dan lutut. Teknik serangan bela diri muaythai yaitu cherng muay berarti metode penggunaan tinju, kaki, lutut dan siku dalam seni bela diri muaythai sebagai keterampilan pertahanan serangan. Cherng Muay dibagi menjadi empat yaitu: (1) Cherng Mad 15 Cherng (pukulan), (2) Cherng Sok 24 Cherng (sikuan), (3) Cherng Khao 11 Cherng (lutut), (4) Cherng Thao 15 Cherng (tendangan) (Montoya, 2019; Orhan, Yücel, Sadeq, \& Orhan, 2019).

\section{Kondisi Fisik}

Kondisi fisik merupakan kebutuhan yang paling dasar dalam olahraga, kondisi fisik merupakan unsur yang sangat penting hampir diseluruh cabang olahraga membutuhkan kondisi fisik yang prima, karena kondisi fisik yang baik akan menunjang kemampuan teknik dan taktik atlet saat melakukan pertandingan. Pengertian kondisi fisik dalam olahraga adalah suatu kualitas fisik, kualitas psikis dan kemampuan fungsional dalam tubuh individu dalam memenuhi tuntutan prestasi yang optimal pada spesifikasi dalam cabang olahraga tertentu (Arhant, Wogritsch, \& Troxler, 2015; Chan, Pua, \& How, 2017; Kendzierski \& DeCarlo, 2016).

\section{Kekuatan (Stength)}

Kekuatan adalah kemampuan otot untuk melakukan kontraksi yang berguna untuk membangkitkan ketegangan terhadap suatu tahanan (Kraus, Schütz, Taylor, \& Doyscher, 2014; Ransdell \& Murray, 2016). Kekuatan merupakan komponen kondisi fisik seseorang tentang kemampuan dalam mempergunakan otototot untuk menerima beban sewaktu kerja (Lloyd \& Oliver, 2012; Mora-Gonzalez et al., 2019). Jadi dapat disimpulkan bahwa kekuatan merupakan kemampuan otot untuk menerima beban berlebih dan membangkitkan tenaga terhadap suatu beban tahanan dengan waktu kerja tertentu.

\section{Daya Ledak (Power)}

Daya ledak atau power adalah hasil dari kekuatan dan kecepatan (Behm et al., 2017; Chaabene, Prieske, Negra, \& Granacher, 2018). Power adalah kemampuan otot untuk mengerjakan kekuatan maksimal dalam waktu yang sangat cepat. Daya ledak adalah kemampuan seseorang dalam mempergunakan kekuatan 
maksimum yang dilakukan dalam waktu yang sependek-pendeknya (Collins \& Staples, 2017; Voss et al., 2016). Dengan demikian kekuatan atau power merupakan perpaduan antara kekuatan dan kelincahan, sehingga untuk mempunyai power yang baik harus mengembangkan kekuatan dan kecepatan.

\section{Kecepatan (Speed)}

Menurut Karadimas et al. (2020) Kecepatan adalah jarak tempuh per satuan waktu yang diukur dalam menit atau skala kuantitas, kecepatan yaitu kemampuan melakukan gerakan dalam periode waktu yang pendek. Kecepatan adalah kemampuan seseorang untuk menentukan jarak tertentu dalam waktu sesingkatsingkatnya (Frost, Beach, Callaghan, \& McGill, 2015; Severi et al., 2014). Kecepatan adalah kemampuan seseorang mengerjakan gerakan berkesinambungan dalam bentuk yang sama dan dalam waktu yang sesingkat-singkatnya (Galea, Mallia, Rothwell, \& Diedrichsen, 2015; Golub, Yu, Schwartz, \& Chase, 2014; Statton, Encarnacion, Celnik, \& Bastian, 2015). Dapat disimpulkan bahwa kecepatan adalah melakukan gerakan dengan jarak waktu sesingkat-singkatnya secara sistematis dan berurutan.

\section{Daya Tahan Jantung (cardiovascular Endurance)}

Hellsten \& Nyberg (2016) menjelaskan bahwa daya tahan adalah kemampuan otot dalam melakukan suatu aktivitas atau latiahan dalam waktu yang lama tampa merasakan lelah yang berlebih. Daya tahan adalah kemampuan otot berkontraksi dalam beberapa waktu tanpa mengalami kelelahan (Hickson, Dvorak, Gorostiaga, Kurowski, \& Foster, 1988; Volek, Noakes, \& Phinney, 2015). Dari pengertian di atas dapat disimpulkan bahwa daya tahan adalah kemampuan kerja otot untuk berkontraksi dalam melakukan aktivitas atau latihan dalam waktu yang relatif lama tanpa mengalami kelelahan setelah melakukan aktivitas tesebut.

\section{METODE}

Penelitian ini merupakan penelitian deskriptif kuantitatif dengan metode survei dengan teknik pengumpulan data menggunakan tes dan pengukuran. Metode ini digunakan untuk mengumpulkan data mengenai gambaran kondisi fisik dengan mengunakan berbagai tes kondisi fisik antara lain: (1) Kekuatan otot perut dengan tes sit up 30 detik, (2) Kekuatan otot lengan dengan tes push up 30 detik, (3) Daya ledak otot tungkai dengan test standing long jump, (4) Kecepatan dengan tes lari sprint 30 meter, (5) Daya tahan dengan multi stage fitness test atau bleep test. Berdasarkan permasalahan yang diteliti, maka peneliti menggunakan rancangan penelitian berbentuk deskriptif kuantitatif yaitu paparan data yang berbentuk angka dijadikan sebuah kalimat, dengan menggunakan teknik survei. Survei adalah penelitian yang mengambil sempel dari satu populasi dan menggunakan kuesioner sebagai alat pengumpulan data yang pokok (Jamshed, 2014).

\section{HASIL}

Berikut ini merupakan tabel dari hasil penelitian terkait dengan tes kondisi fisik terhadap atlet muaythai pusat pelatihan Kabupaten Malang, yang dikelompokkan berdasarkan usia dan jenis kelamin, sebagai berikut:

\section{Tes Kekuatan (Strenght)}

Tabel 1 Hasil Tes Sit Up Atlet Muaythai (Putra)

\begin{tabular}{|c|c|c|c|c|}
\hline No & $\begin{array}{l}\text { Kelas Interval } \\
\text { (/60 detik) }\end{array}$ & Kategori & Frekuensi & Persentase (\%) \\
\hline 1 & $\geq 48$ & Sangat Baik & 1 & $16 \%$ \\
\hline 2 & $42-47$ & Baik & 0 & $0 \%$ \\
\hline 3 & $38-41$ & Cukup & 1 & $17 \%$ \\
\hline 4 & $33-37$ & Kurang & 3 & $50 \%$ \\
\hline \multirow[t]{5}{*}{5} & $\leq 32$ & Sangat Kurang & 1 & $17 \%$ \\
\hline & Jumlah & & 6 & 100 \\
\hline & Rata-rata & & 36 (/60 detik) & \\
\hline & Skor Maksimum & & 48 (/60 detik) & \\
\hline & Skor Minimum & & 29 (/60 detik) & \\
\hline
\end{tabular}


Berdasarkan hasil penelitian tes sit up tersebut yang telah dilakukan kepada 6 atlet muaythai laki-laki, pada tebel 1 diperoleh hasil berdasarkan kategori sangat baik sebanyak 1 orang $(17 \%)$, kategori baik 0 orang $(0 \%)$, kategori cukup 1 orang (17\%), kategori kurang 3 orang (50\%), dan kategori sangat kurang 1 orang (16\%). Nilai rata-rata sit up yaitu sejumlah $36 / 60$ detik, dengan skor maksimum 48 /60 detik dan skor minimum 29 /60 detik.

Tabel 2 Hasil Tes Sit Up Atlet Muaythai (Putri)

\begin{tabular}{|c|c|c|c|c|}
\hline No & $\begin{array}{l}\text { Kelas Interval } \\
\text { (/60 detik) }\end{array}$ & Kategori & Frekuensi & $\begin{array}{c}\text { Persentase } \\
(\%)\end{array}$ \\
\hline 1 & $\geq 42$ & Sangat Baik & 0 & $0 \%$ \\
\hline 2 & $36-41$ & Baik & 0 & $0 \%$ \\
\hline 3 & $31-35$ & Cukup & 2 & $67 \%$ \\
\hline 4 & $27-30$ & Kurang & 1 & $33 \%$ \\
\hline 5 & $\leq 26$ & Sangat Kurang & 0 & $0 \%$ \\
\hline \multicolumn{3}{|c|}{ Jumlah } & 3 & 100 \\
\hline \multicolumn{3}{|c|}{ Rata-Rata } & 31 (/60 detik) & \\
\hline \multicolumn{3}{|c|}{ Skor Maksimum } & 34 (/60 detik) & \\
\hline \multicolumn{3}{|c|}{ Skor Minimum } & 28 (/60 detik) & \\
\hline
\end{tabular}

Berdasarkan hasil penelitian tes sit up tersebut yang telah dilakukan kepada 3 atlet muaythai putri, pada tebel 2 diproleh hasil berdasarkan kategori tes sit up sangat baik sebanyak 0 orang $(0 \%)$, kategori baik 0 orang $(0 \%)$, kategori cukup 2 orang $(67 \%)$, kategori kurang 1 orang $(33 \%)$, kategori sangat kurang 0 orang $(0 \%)$. Diperoleh nilai rata-rata hasil tes sit up yaitu berjumlah $31 / 60$ detik, dengan skor maksimum $34 / 60$ detik dan skor minimum $28 / 60$ detik.

Kekuatan Otot Lengan, push Up

Tabel 3 Hasil Tes Push Up Atlet Muaythai (Putra)

\begin{tabular}{|c|c|c|c|c|}
\hline No & $\begin{array}{l}\text { Kelas Interval } \\
\text { (/60 detik) }\end{array}$ & Kategori & Frekuensi & Persentase (\%) \\
\hline 1 & $70-$ ke atas & Baik Sekali & 0 & $0 \%$ \\
\hline 2 & $54-69$ & Baik & 0 & $0 \%$ \\
\hline 3 & $38-58$ & Sedang & 2 & $33 \%$ \\
\hline 4 & $22-37$ & Kurang & 4 & $67 \%$ \\
\hline 5 & ke bawah -21 & Kurang Sekali & 0 & $0 \%$ \\
\hline & \multicolumn{2}{|c|}{ Jumlah } & 6 & 100 \\
\hline & \multicolumn{2}{|c|}{ Rata-rata } & 36 (/60 detik) & \\
\hline & \multicolumn{2}{|c|}{ Skor Maksimum } & 41 (/60 detik) & \\
\hline & \multicolumn{2}{|c|}{ Skor Minimum } & 32 (/60 detik) & \\
\hline
\end{tabular}

Berdasarkan hasil penilaian tes push up yang telah dilakukan kepada 6 atlet muaythai laki-laki, pada tabel 3 diperoleh hasil berdasarkan kategori baik sekali sebanyak 0 orang $(0 \%)$, kategori baik 0 orang $(0 \%)$, kategori sedang 2 orang (33\%), kategori kurang 3 orang $(67 \%)$, kategori kurang sekali 0 orang $(0 \%)$. Sedangkan nilai rata-rata hasil tes push up yaitu berjumlah $36 / 60$ detik, dengan skor maksimum $48 / 60$ detik dan skor minimum $29 / 60$ detik. 
Tabel 4 Hasil Tes Push Up Atlet Muaythai (Putri)

\begin{tabular}{|c|c|c|c|c|}
\hline No & $\begin{array}{l}\text { Kelas Interval } \\
\text { (/60 detik) }\end{array}$ & Kategori & Frekuensi & Persentase(\%) \\
\hline 1 & $70-$ ke atas & Baik Sekali & 0 & $0 \%$ \\
\hline 2 & $54-69$ & Baik & 0 & $0 \%$ \\
\hline 3 & $38-58$ & Sedang & 0 & $0 \%$ \\
\hline 4 & $22-37$ & Kurang & 3 & $100 \%$ \\
\hline \multirow[t]{5}{*}{5} & ke bawah -21 & Kurang Sekali & 0 & $0 \%$ \\
\hline & Jumlah & & 3 & 100 \\
\hline & Rata-rata & & 30 (/60 detik) & \\
\hline & Skor Maksimum & & 35 (/60 detik) & \\
\hline & Skor Minimum & & 26 (/60 detik) & \\
\hline
\end{tabular}

Berdasarkan penilaian tes tersebut yang dilakukan pada 3 atlet muaythai putri, pada tabel 4 diproleh hasil berdasarkan kategori tes push up baik sekali sebanyak 0 orang $(0 \%)$, kategori baik 0 orang $(0 \%)$, kategori sedang 0 orang $(0 \%)$, kategori kurang 3 orang $(100 \%)$, kategori kurang sekali 0 orang $(0 \%)$. Diperoleh nilai rata-rata hasil tes push up yaitu berjumlah $30 / 60$ detik, dengan skor maksimum $35 / 60$ detik dan skor minimum $26 / 60$ detik.

Tabel 5 Hasil Tes Standing Long Jump Atlet Muaythai (Putra)

\begin{tabular}{|c|c|c|c|c|}
\hline No & Kelas Interval & Kategori & Frekuensi & Persentase (\%) \\
\hline 1 & $>250$ & Baik Sekali & 1 & $16 \%$ \\
\hline 2 & $241-250$ & Baik & 0 & $0 \%$ \\
\hline 3 & $231-240$ & Cukup & 1 & $17 \%$ \\
\hline 4 & $221-230$ & Sedang & 1 & $17 \%$ \\
\hline 5 & $211-220$ & Kurang & 2 & $33 \%$ \\
\hline 6 & $191-210$ & Poor & 1 & $17 \%$ \\
\hline 7 & $<191$ & Very Poor & 0 & $0 \%$ \\
\hline \multicolumn{3}{|c|}{ Jumlah } & 6 & 100 \\
\hline \multicolumn{3}{|c|}{ Rata-rata } & $229(\mathrm{~cm})$ & \\
\hline \multicolumn{3}{|c|}{ Skor Maksimum } & $260(\mathrm{~cm})$ & \\
\hline \multicolumn{3}{|c|}{ Skor Minimum } & $210(\mathrm{~cm})$ & \\
\hline
\end{tabular}

Berdasarkan hasil penelitian tes standing long jump yang telah dilakukan terhadap seluruh atlet muaythai putri pusat pelatiahan Kabupaten Malang yang berjumlah 3 orang, pada tebel 5 diperoleh hasil penelitian tes standing long jump yang telah dilakukan didapati kategori baik sekali sebanyak 1 orang $(0 \%)$, kategori baik 0 orang $(0 \%)$, kategori cukup 1 orang $(17 \%)$, kategori sedang 1 orang $(17 \%)$, kategori kurang 2 orang $(33 \%)$, kategori poor 1 orang $(17 \%)$, kategori very poor $(0 \%)$. Sedangkan nilai rata-rata tes standing long jump yaitu sejumlah $229 \mathrm{~cm}$, dengan dengan skor maksimum $260 \mathrm{~cm}$ dan skor minimum $210 \mathrm{~cm}$. 
Tabel 6 Hasil Tes Standing Long Jump Atlet Muaythai (Putri)

\begin{tabular}{|c|c|c|c|c|}
\hline No & Kelas Interval & Kategori & Frekuensi & Persentase (\%) \\
\hline 1 & $>200$ & Baik Sekali & 0 & $0 \%$ \\
\hline 2 & $191-200$ & Baik & 1 & $33 \%$ \\
\hline 3 & $181-190$ & Cukup & 0 & $0 \%$ \\
\hline 4 & $171-180$ & Sedang & 1 & $34 \%$ \\
\hline 5 & $161-170$ & Kurang & 1 & $33 \%$ \\
\hline 6 & $141-160$ & Poor & 0 & $0 \%$ \\
\hline \multirow[t]{5}{*}{7} & $<141$ & Very Poor & 0 & $0 \%$ \\
\hline & Jumlah & & 3 & 100 \\
\hline & Rata-rata & & $183(\mathrm{~cm})$ & \\
\hline & Skor maksimum & & $200(\mathrm{~cm})$ & \\
\hline & Skor Minimum & & $170(\mathrm{~cm})$ & \\
\hline
\end{tabular}

Berdasarkan hasil penelitian tes Standing Long Jump yang telah dilakukan kepada seluruh atlet muaythai putri pusat pelatiahan Kabupaten Malang yang berjumlah 3 orang, pada tabel 6 deperoleh hasil penelitian tes standing long jump yang telah dilakukan didapati kategori baik sekali sebanyak 0 orang (0\%), kategori baik 1 orang $(33 \%)$, kategori cukup 0 orang $(0 \%)$, kategori sedang 1 orang $(34 \%)$, kategori kurang 1 orang $(33 \%)$, kategori poor 0 orang $(0 \%)$, kategori very poor $(0 \%)$. Sedangkan nilai rata-rata tes standing long jump yaitu sejumlah $183 \mathrm{~cm}$, dengan dengan skor maksimum $200 \mathrm{~cm}$ dan skor minimum $170 \mathrm{~cm}$.

Hasil Tes Kecepatan (Speed) Sprint 30 Meter

Tabel 7 Hasil Tes Hasil Tes Sprint 30 Meter Atlet Muaythai (Putra)

\begin{tabular}{|c|c|c|c|c|}
\hline No & Kelas Interval & Kategori & Frekuensi & Persentase (\%) \\
\hline 1 & $<4.0$ detik & Unggul & 2 & $33 \%$ \\
\hline 2 & $4,2-4,0$ detik & Di atas rata-rata & 2 & $33 \%$ \\
\hline 3 & $4,4-4,3$ detik & Rata-rata & 2 & $34 \%$ \\
\hline 4 & $4,6-4,5$ detik & Di bawah rata-rata & 0 & $0 \%$ \\
\hline 5 & $>4,6$ detik & Kurang & 0 & $0 \%$ \\
\hline \multicolumn{3}{|c|}{ Jumlah } & 6 & 100 \\
\hline \multicolumn{3}{|c|}{ Rata-rata } & 4,08 (meter/detik) & \\
\hline \multicolumn{3}{|c|}{ Skor Maksimum } & 4,33 (meter/detik) & \\
\hline \multicolumn{3}{|c|}{ Skor Mininimum } & 3,67 (meter/detik) & \\
\hline
\end{tabular}

Berdasarkan hasil dari penelitian tes tersebut yang telah dilakukan kepada atlet muythai berjenis kelamin lakilaki, diperoleh hasil persentase yaitu kategori kategori unggul sebanyak 2 orang (33\%), di atas rata-rata 2 orang (33\%), rata-rata 2 orang (34\%), kategori di bawah rata-rata 0 orang $(0 \%)$, kategori kurang 0 orang $(0 \%)$. Dengan nilai rata-rata yang diperoleh tes sprint atlet muythai putra yaitu sejumlah 4,08 meter/detik, dengan dengan skor maksimum 4,33 meter/detik dan skor minimum 3,67 meter/detik. 
Tabel 8 Hasil Tes Hasil Tes Sprint 30 Meter Atlet Muaythai (Putri)

\begin{tabular}{|c|c|c|c|c|}
\hline No & Kelas Interval & Kategori & Frekuensi & Persentase (\%) \\
\hline 1 & $<4,5$ detik & Unggul & 0 & $0 \%$ \\
\hline 2 & $4,6-4,5$ detik & Di atas rata-rata & 0 & $0 \%$ \\
\hline 3 & $4,8-4,7$ detik & Rata-rata & 0 & $0 \%$ \\
\hline 4 & $5,0-4,9$ detik & Di bawah rata-rata & 2 & $67 \%$ \\
\hline \multirow[t]{5}{*}{5} & $>5.0$ detik & Kurang & 1 & $33 \%$ \\
\hline & Jumlah & & 3 & 100 \\
\hline & Rata-rata & & 5,04 (meter/detik) & \\
\hline & Skor Maksimal & & 5,06 (meter/detik) & \\
\hline & Skor Minimal & & 5,03 (meter/detik) & \\
\hline
\end{tabular}

Berdasarkan hasil dari penelitian tes sprint yang telah dilakukan kepada atlet muythai berjenis kelamin putri, pada tabel 8 diperoleh hasil persentase atlet muaythai putri yaitu kategori kategori unggul sebanyak 0 orang $(0 \%)$, di atas rata-rata 0 orang $(0 \%)$, rata-rata 0 orang $(0 \%)$, kategori di bawah rata-rata 2 orang $(67 \%)$, kategori kurang 1 orang (33\%). Dengan nilai rata-rata yang diperoleh tes sprint atlet muythai putri yaitu sejumlah 5,04 meter/detik, dengan dengan skor maksimum 5,06 meter/detik dan skor minimum 5,03 meter/detik.

Hasil Tes Daya Tahan, Vo2max

Tabel 9 Distribusi Data Vo2max Atlet Muaythai (Putra)

\begin{tabular}{|c|c|c|c|c|}
\hline No & Kelas Interval & Kategori & Frekuensi & Persentase(\%) \\
\hline 1 & $<35,0$ & Jelek & 0 & $0 \%$ \\
\hline 2 & $35,0-39,9$ & Di bawah rata-rata & 0 & $0 \%$ \\
\hline 3 & $40,5-45,1$ & Rata-Rata & 4 & $67 \%$ \\
\hline 4 & $45,2-50,9$ & Di atas rata-rata & 0 & $0 \%$ \\
\hline 5 & $51,0-55,9$ & Baik & 2 & $33 \%$ \\
\hline \multirow[t]{5}{*}{6} & $>55,9$ & Sangat Baik & 0 & $0 \%$ \\
\hline & Jumlah & & 6 & 100 \\
\hline & Rata-rata & & $46,1 \mathrm{ml} / \mathrm{kg} /$ menit & \\
\hline & Skor Maksimal & & $51,4 \mathrm{ml} / \mathrm{kg} / \mathrm{menit}$ & \\
\hline & Skor Minimal & & $42,2 \mathrm{ml} / \mathrm{kg} / \mathrm{menit}$ & \\
\hline
\end{tabular}

Berdasarkan hasil dari penelitian tes vo2max yang telah dilakukan kepada atlet muythai berjenis kelamin lakilaki, pada tabel 9 diperoleh hasil berdasarkan kategori vo2max sangat baik sebanyak 0 orang (0\%), baik 2 $(33 \%)$, di atas rata-rata $(0 \%)$, rata-rata 4 orang $(67 \%)$, Di bawah rata-rata 0 orang $(0 \%)$, jelek 0 orang $(0 \%)$. Dan diproleh nilai rata-rata tes vo2max yaitu sejumlah $46,1 \mathrm{ml} / \mathrm{kg} / \mathrm{menit}$, dengan dengan skor maksimum 51,4 $\mathrm{ml} / \mathrm{kg} /$ menit dan skor minimum $42,2 \mathrm{ml} / \mathrm{kg} /$ menit. 
Tabel 10 Distribusi Data Vo2max Atlet Muaythai (Putri)

\begin{tabular}{|c|c|c|c|c|}
\hline No & Kelas Interval & Kategori & Frekuensi & Persentase(\%) \\
\hline 1 & $<33,0$ & Jelek & 0 & $0 \%$ \\
\hline 2 & $33,0-37,1$ & Di bawah rata-rata & 3 & $100 \%$ \\
\hline 3 & $37,8-42,4$ & Rata-Rata & 0 & $0 \%$ \\
\hline 4 & $43,3-46,8$ & Di atas rata-rata & 0 & $0 \%$ \\
\hline 5 & $47,4-52,5$ & Baik & 0 & $0 \%$ \\
\hline 6 & $>52,6$ & Sangat Baik & 0 & $0 \%$ \\
\hline \multicolumn{3}{|c|}{ Jumlah } & 3 & 100 \\
\hline \multicolumn{3}{|c|}{ Rata-rata } & \multicolumn{2}{|l|}{$35,5 \mathrm{ml} / \mathrm{kg} /$ menit } \\
\hline \multicolumn{3}{|c|}{ Skor Maksimum } & \multicolumn{2}{|l|}{$37,1 \mathrm{ml} / \mathrm{kg} /$ menit } \\
\hline \multicolumn{3}{|c|}{ Skor Minimum } & \multicolumn{2}{|l|}{$32,6 \mathrm{ml} / \mathrm{kg} /$ menit } \\
\hline
\end{tabular}

Berdasarkan hasil dari penelitian tes vo2max yang telah dilakukan kepada atlet muythai berjenis kelamin putri yang berjumlah 3 orang, pada tabel 10 didapati kategori sangat baik sebanyak 0 orang $(0 \%)$, baik $0(0 \%)$, di atas rata-rata $(0 \%)$, rata-rata 0 orang $(0 \%)$, Di bawah rata-rata 3 orang $(100 \%)$, jelek 0 orang $(0 \%)$. Serta diproleh nilai rata-rata tes vo2max yaitu sejumlah $35,5 \mathrm{ml} / \mathrm{kg} / \mathrm{menit}$, dengan dengan skor maksimum 37,1 $\mathrm{ml} / \mathrm{kg} /$ menit dan skor minimum $32,6 \mathrm{ml} / \mathrm{kg} /$ menit.

\section{PEMBAHASAN}

Pada peneliti ini penulis akan membahas tentang kondisi fisik Atlet Muaythai Pusat Pelatihan Kabupaten Malang yang telah dilakukan tes kondisi fisik. Dari hasil penelitian ini, atlet muaythai diberikan tes sit up 60 detik, tes push up 60 detik, standing long jump, tes sprint 30 meter, tes multi stage fitness test atau bleep test, dengan tujuan untuk mengetahui tingkat kondisi fisik Atlet Muaythai Pusat Pelatihan Kabupaten Malang. Pemberian tes tersebut sesuai dengan kebutuhan Atlet Muaythai Pusat Pelatihan Kabupaten Malang, berdasarkan usia dan jenis kelaminnya. Berikut pembahasan tentang hasil tes kondisi fisik Atlet Muaythai Pusat Pelatihan Kabupaten Malang.

\section{Kekuatan Otot Perut (Sit Up)}

Penilaian norma stadarisasi tes sit up yang berjenis kelamin laki-laki dikategorikan sebagai berikut, kategori sangat baik $>48$, baik 42-47, cukup 38-41, kurang 33-37, sangat kurang $<32$. Dari hasil penelitian tes sit up tersebut yang telah dilakukan kepada 6 atlet muaythai laki-laki, diperoleh hasil berdasarkan kategori sangat baik sebanyak 1 orang (16\%), kategori baik 0 orang (0\%), kategori cukup 1 orang (17\%), kategori kurang 3 orang $(50 \%)$, dan kategori sangat kurang 1 orang (17\%). Nilai rata-rata sit up yaitu sejumlah $36 / 60$ detik, dengan skor maksimum $48 / 60$ detik dan skor minimum $29 / 60$ detik. Penilaian norma standarisasi sit up atlet perempuan yang berjumlah 3 orang dapat dikategorikan sebagai berikut, kategori sangat baik $>42$, baik 36 41 , cukup 31-35, kurang 27-30, sangat kurang <26. Dari hasil penilaian tes diproleh hasil berdasarkan kategori tes sit up sangat baik sebanyak 0 orang $(0 \%)$, kategori baik 0 orang $(0 \%)$, kategori cukup 2 orang $(67 \%)$, kategori kurang 1 orang (33\%), kategori sangat kurang 0 orang $(0 \%)$. Diperoleh nilai rata-rata hasil tes sit up yaitu berjumlah 31 /60 detik, dengan skor maksimum 34 /60 detik dan skor minimum $28 / 60$ detik. Sedangkan berdasarkan penelitian kondisi fisik atlet muaythai putri, menunjukkan bahwa tes sit up atlet muaythai putri masuk pada kategori cukup.

\section{Kekuatan Otot Lengan (Push Up)}

Penilaian norma stadarisasi push up pada atlet yang berjenis kelamin laki-laki dikategorikan sebagai berikut, kategori sangat baik $>70$, baik 54-69, sedang 38-53, kurang 22-37, sangat kurang $<21$. Berdasarkan hasil penilaian tes push up yang telah dilakukan kepada 6 atlet muaythai laki-laki, diperoleh hasil berdasarkan kategori baik sekali sebanyak 0 orang $(0 \%)$, kategori baik 0 orang $(0 \%)$, kategori sedang 2 orang $(33 \%)$, kategori kurang 3 orang (67\%), kategori kurang sekali 0 orang (0\%). nilai rata-rata hasil tes push up yaitu berjumlah 36 /60 detik, dengan skor maksimum 41/60 detik dan skor minimum 32 /60 detik. Penilaian norma 
standarisasi tes push up dengan waktu 60 detik berdasarkan jenis kelamin perempuan dapat dikategorikan sebagai berikut, kategori sangat baik > 70, baik 54-69, cukup 31-35, sedang 35-53, kurang 22-34, sangat kurang $<21$. Dari hasil penilaian tes tersebut yang dilakukan pada 3 atlet muaythai putri, diproleh hasil berdasarkan kategori tes push up baik sekali sebanyak 0 orang $(0 \%)$, kategori baik 0 orang $(0 \%)$, kategori sedang 0 orang $(0 \%)$, kategori kurang 3 orang $(100 \%)$, kategori kurang sekali 0 orang $(0 \%)$. Diperoleh nilai rata-rata hasil tes push up yaitu berjumlah $30 / 60$ detik, dengan skor maksimum $35 / 60$ detik dan skor minimum $26 / 60$ detik.

\section{Tes Daya Ledak (Power)}

Pada penelitian kondisi fisik terhadap atlet muaythai pusat pelatihan Kabupaten Malang, menggunakan norma standarisai tes standing long jump pada jenis kelamin laki-laki dikategorikan sebagai berikut kategori baik sekali > 250, kategori baik 241-250, kategori cukup 231-240, kategori sedang, 221-230, kategori kurang 211220, kategori poor 191-210, kategori very poor < 191. Dari hasil penelitian tes standing long jump yang telah dilakukan terhadap seluruh atlet muaythai putri pusat pelatiahan Kabupaten Malang yang berjumlah 3 orang, pada tebel diperoleh hasil penelitian tes standing long jump yang telah dilakukan didapati kategori baik sekali sebanyak 1 orang $(0 \%)$, kategori baik 0 orang $(0 \%)$, kategori cukup 1 orang $(17 \%)$, kategori sedang 1 orang $(17 \%)$, kategori kurang 2 orang $(33 \%)$, kategori poor 1 orang $(17 \%)$, kategori very poor $(0 \%)$. Penilaian norma standarisasi standing long jump berdasarkan jenis kelamin perempuan dapat dikategorikan sebagai berikut, kategori baik sekali > 200, kategori baik 191-200, kategori cukup 181-190, kategori sedang 171-180, kategori kurang 161-170, kategori poor 141-160, kategori very poor $<141$. Dari hasil penelitian tes standing long jump yang telah dilakukan terhadap seluruh atlet muaythai putri pusat pelatiahan Kabupaten Malang yang berjumlah 3 orang, diperoleh hasil penelitian tes standing long jump yang telah dilakukan didapati kategori baik sekali sebanyak 0 orang $(0 \%)$, kategori baik 1 orang (33\%), kategori cukup 0 orang $(0 \%)$, kategori sedang 1 orang $(34 \%)$, kategori kurang 1 orang (33\%), kategori poor 0 orang $(0 \%)$, kategori very poor $(0 \%)$.

\section{Tes Kecepatan (Sprint 30 Meter)}

Pada penelitian kondisi fisik terhadap atlet muaythai pusat pelatihan Kabupaten Malang, menggunakan norma standarisai berdasarkan jenis kelamin laki-laki yang dikategorikan sebagai berikut, kategori unggul $<4.0$ detik, di atas rata-rata 4,2-4,0 detik, rata-rata 4,4-4,3 detik, di bawah rata-rata 4,6-4,5 detik, kurang > 4,6 detik. Berdasarkan hasil dari penelitian tes tersebut yang telah dilakukan kepada atlet muythai berjenis kelamin lakilaki, diperoleh hasil persentase yaitu kategori kategori unggul sebanyak 2 orang (33\%), di atas rata-rata 2 orang (33\%), rata-rata 2 orang (34\%), kategori di bawah rata-rata 0 orang $(0 \%)$, kategori kurang 0 orang $(0 \%)$. Dengan nilai rata-rata yang diperoleh tes sprint atlet muythai putra yaitu sejumlah 4,08 meter/detik, dengan dengan skor maksimum 4,33 meter/detik dan skor minimum 3,67 meter/detik. Dari hasil penelitian tes sprint 30 yang telah dilakukan terhadap seluruh atlet muaythai putri, diperoleh hasil kategori unggul $<4,5$ detik, di atas rata-rata 4,6-4,5 detik, rata-rata 4,8-4,7 detik, di bawah rata-rata 5,0-4,9 detik, > 5.0 detik. Berhasilkan hasil tes tersebut yang dilakukan kepada atlet muaythai putri, diperoleh hasil persentase yaitu kategori kategori unggul sebanyak 0 orang $(0 \%)$, di atas rata-rata 0 orang $(0 \%)$, rata-rata 0 orang $(0 \%)$, kategori di bawah ratarata 2 orang $(67 \%)$, kategori kurang 1 orang (33\%). Dengan nilai rata-rata yang diperoleh tes sprint atlet muythai putri yaitu sejumlah 5,04 meter/detik, dengan dengan skor maksimum 5,06 meter/detik dan skor minimum 5,03 meter/detik.

\section{Daya Tahan, Vo2max}

Penilaian norma standarisasi vo2max vo2max berdasarkan jenis kelamin perempuan dikategorikan sebagai berikut, sangat baik $>52,6$, baik $52,5-47,4$, di atas rata-rata $46,8-43,3$, rata-rata $42,4-37,8$, di bawah ratarata $37,1-33,0$, jelek $<33,0$. Berdasarkan hasil dari penelitian tes tersebut yang telah dilakukan kepada atlet muythai berjenis kelamin putri, kategori sangat baik sebanyak 0 orang $(0 \%)$, baik $0(0 \%)$, di atas rata-rata $(0 \%)$, rata-rata 0 orang $(0 \%)$, Di bawah rata-rata 3 orang $(100 \%)$, jelek 0 orang $(0 \%)$. Serta diproleh nilai ratarata tes vo2max yaitu sejumlah $35,5 \mathrm{ml} / \mathrm{kg} / \mathrm{menit}$, dengan dengan skor maksimum $37,1 \mathrm{ml} / \mathrm{kg} / \mathrm{menit}$ dan skor minimum $32,6 \mathrm{ml} / \mathrm{kg} /$ menit. Sedangkan berdasarkan jenis kelamin laki-laki dikategorikan sebagai berikut, sangat baik $>55,9$, baik 55,9-51,0, di atas rata-rata 50,9-45,2, rata-rata 45,1-40,5, di bawah rata-rata $39,9-35,0$, jelek $<35,0$. Berdasarkan hasil dari penelitian tes tersebut yang telah dilakukan kepada atlet muythai berjenis kelamin laki-laki, diperoleh hasil berdasarkan kategori vo2max sangat baik sebanyak 0 orang $(0 \%)$, baik $2(33 \%)$, di atas rata-rata $(0 \%)$, rata-rata 4 orang $(67 \%)$, Di bawah rata-rata 0 orang $(0 \%)$, jelek 0 
orang (0\%). Dan diproleh nilai rata-rata tes vo2max yaitu sejumlah $46,1 \mathrm{ml} / \mathrm{kg} / \mathrm{menit}$, dengan dengan skor maksimum 51,4 $\mathrm{ml} / \mathrm{kg} / \mathrm{menit}$ dan skor minimum $42,2 \mathrm{ml} / \mathrm{kg} / \mathrm{menit}$. Penilaian norma standarisasi.

\section{KESIMPULAN}

Berdasarkan hasil penelitian survei kondisi fisik atlet muaythai pusat pelatihan Kabupaten Malang, dari hasil analisis data dan pembahasan, maka dapat ditarik kesimpulan, yaitu: Kondisi fisik atlet Muaythai putra pusat pelatihan Kabupaten Malang kategori kondisi fisik atlet muaythai putra pusat pelatihan Kabupaten Malang masuk pada kategori "kurang". Sedangkan Kondisi fisik atlet muaythai putri pusat pelatihan Kabupaten Malang masuk pada kategori "sedang". Dari hasil penelitian dan kesimpulan mengenai kondisi fisik atlet muaythai pusat pelatihan Kabupaten Malang, beberapa saran yang dapat dikemukakan yang ditunjukkan kepada beberapa pihak antara lain sebagai berikut. Bagi pelatih peneliti menyarankan agar kondisi fisik atlet muaythai pusat pelatihan Kabupaten Malang harus diditingkatkan, dengan merancang program latihan yang dapat meningkatkan kondisi fisik atlet sehingga atlet dapat mencapai prestasi yang maksimal. Bagi atlet muaythai pusat pelatihan Kabupaten Malang harus meningkatkan latihan kondisi fisiknya, dengan menambah latihan secara mandiri diluar jadwal latihan yang telah ditentukan.

\section{Ucapan Terima Kasih}

Peneliti menyadari, bahwa dalam penulisan skripsi ini tidak akan selesai tanpa bantuan dari berbagai pihak. Sehingga dikesempatan yang baik ini peneliti mengucapkan terimakasih yang sebesar-besarya kepada Dr. Sapto Adi, M.Kes., selaku Dekan Fakultas IImu Keolahragaan Universitas Negeri Malang, yang telah memberikan kesempatan bagi peneliti untuk menyelesaikan pendidikan dan menempuh jenjang sarjana di FIK UM, Dr. dr. Moch. Yunus, M.Kes., sebagai Wakil Dekan I Fakultas IImu Keolahragaan yang telah membantu dan memberikan izin dalam proses penelitian, Dr. Lokananta Teguh Hari Wiguno, M.Kes., selaku Ketua Jurusan Pendidikan Jasmani dan Kesehatan Fakultas IImu Keolahragaan, Dr. Eko Hariyanto, M.Pd., selaku Dosen Pembimbing I yang telah meluangkan waktu memberikan bimbingan, memberikan motivasi.

\section{DAFTAR PUSTAKA}

Aidar, F. J., Gama De Matos, D., De Souza, R. F., Gomes, A. B., Saavedra, F., Garrido, N., .. Reis, V. (2018). Influence of aquatic exercises in physical condition in patients with multiple sclerosis. Journal of Sports Medicine and Physical Fitness. https://doi.org/10.23736/S0022-4707.17.07151-1

Alim, A. (2015). Pengaruh Olahraga Terprogram Terhadap Tekanan Darah Dan Daya Tahan Kardiorespirasi Pada Atlet Pelatda Sleman Cabang Tenis Lapangan. MEDIKORA. https://doi.org/10.21831/medikora.v0i2.4651

Alit Arsani, N. L. K. (2014). Manajemen Gizi Atlet Cabang Olahraga Unggulan Di Kabupaten Buleleng. JST (Jurnal Sains Dan Teknologi). https://doi.org/10.23887/jst-undiksha.v3i1.2906

Arhant, C., Wogritsch, R., \& Troxler, J. (2015). Assessment of behavior and physical condition of shelter cats as animal-based indicators of welfare. Journal of Veterinary Behavior: Clinical Applications and Research. https://doi.org/10.1016/j.jveb.2015.03.006

Behm, D. G., Young, J. D., Whitten, J. H. D., Reid, J. C., Quigley, P. J., Low, J., ... Granacher, U. (2017). Effectiveness of traditional strength vs. power training on muscle strength, power and speed with youth: A systematic review and meta-analysis. Frontiers in Physiology. https://doi.org/10.3389/fphys.2017.00423

Chaabene, H., Prieske, O., Negra, Y., \& Granacher, U. (2018). Change of Direction Speed: Toward a Strength Training Approach with Accentuated Eccentric Muscle Actions. Sports Medicine. https://doi.org/10.1007/s40279-018-0907-3

Chan, H. B. Y., Pua, P. Y., \& How, C. H. (2017). Physical therapy in the management of frozen shoulder. Singapore Medical Journal. https://doi.org/10.11622/smedj.2017107 
Chinnasee, C., Mohamad, N. I., Nadzalan, A. M., Sazili, A. H. A., Hemapandha, W., Pimjan, L., ... Tan, K. (2018). Lower limb kinematics analysis during roundhouse kick among novices in muay thai. Journal of Fundamental and Applied Sciences. https://doi.org/10.4314/jfas.v9i6s.73

Collins, K., \& Staples, K. (2017). The role of physical activity in improving physical fitness in children with intellectual and developmental disabilities. Research in Developmental Disabilities. https://doi.org/10.1016/j.ridd.2017.07.020

Cordoza, K. \&. (2006). Muay Thai unleashed: learn technique and strategy from Thailand's warrior elite. New York: library of congress cataloging-in-publication.

Frost, D. M., Beach, T. A. C., Callaghan, J. P., \& McGill, S. M. (2015). The influence of load and speed on individuals' movement behavior. Journal of Strength and Conditioning Research. https://doi.org/10.1519/JSC.0000000000000264

Galea, J. M., Mallia, E., Rothwell, J., \& Diedrichsen, J. (2015). The dissociable effects of punishment and reward on motor learning. Nature Neuroscience. https://doi.org/10.1038/nn.3956

Golub, M. D., Yu, B. M., Schwartz, A. B., \& Chase, S. M. (2014). Motor cortical control of movement speed with implications for brain-machine interface control. Journal of Neurophysiology. https://doi.org/10.1152/jn.00391.2013

Helen, P. S., Oktia, W. K. H., \& Taufiq, H. (2017). Evaluasi Program Pembinaan Atlet Pekan Olahraga Nasional Cabang Olahraga Bulu Tangkis Provinsi Sumatera Selatan. Journal of Physical Education and Sports.

Hellsten, Y., \& Nyberg, M. (2016). Cardiovascular adaptations to exercise training. Comprehensive Physiology. https://doi.org/10.1002/cphy.c140080

Hickson, R. C., Dvorak, B. A., Gorostiaga, E. M., Kurowski, T. T., \& Foster, C. (1988). Potential for strength and endurance training to amplify endurance performance. Journal of Applied Physiology. https://doi.org/10.1152/jappl.1988.65.5.2285

Hollander, J. A. (2014). Does Self-Defense Training Prevent Sexual Violence Against Women? Violence Against Women. https://doi.org/10.1177/1077801214526046

Jamshed, S. (2014). Qualitative research method-interviewing and observation. Journal of Basic and Clinical Pharmacy. https://doi.org/10.4103/0976-0105.141942

Karadimas, S. K., Satkunendrarajah, K., Laliberte, A. M., Ringuette, D., Weisspapir, I., Li, L., ... Fehlings, M. G. (2020). Sensory cortical control of movement. Nature Neuroscience. https://doi.org/10.1038/s41593019-0536-7

Kendzierski, D., \& DeCarlo, K. J. (2016). Physical Activity Enjoyment Scale: Two Validation Studies. Journal of Sport and Exercise Psychology. https://doi.org/10.1123/jsep.13.1.50

Kraus, K., Schütz, E., Taylor, W. R., \& Doyscher, R. (2014). Efficacy of the functional movement screen: A review. Journal of Strength and Conditioning Research. https://doi.org/10.1519/JSC.0000000000000556

Kumartasli, M., \& Baştuğ, G. (2010). Examination Of Attention Levels Of Athletes Who Do Taekwondo, Karate And Muaythai. Ovidius University Annals, Series Physical Education \& Sport/Science, Movement \& Health.

Lloyd, R. S., \& Oliver, J. L. (2012). The youth physical development model: A new approach to long-term athletic development. Strength and Conditioning Journal. https://doi.org/10.1519/SSC.0b013e31825760ea

Montoya, S. (2019). Las percepciones de la frustracion en un grupo de deportistas de alto rendimiento de Muay Thai en Medellin. Revista de Artes Marciales.

Mora-Gonzalez, J., Esteban-Cornejo, I., Cadenas-Sanchez, C., Migueles, J. H., Molina-Garcia, P., RodriguezAyllon, M., ... Ortega, F. B. (2019). Physical Fitness, Physical Activity, and the Executive Function in Children with Overweight and Obesity. Journal of Pediatrics. https://doi.org/10.1016/j.jpeds.2018.12.028

Moraes, D. C., Lenardt, M. H., Seima, M. D., Mello, B. H. de, Setoguchi, L. S., \& Setlik, C. M. (2019). Postural 
instability and the condition of physical frailty in the elderly. Revista Latino-Americana de Enfermagem. https://doi.org/10.1590/1518-8345.2655-3146

Orhan, S., Yücel, A., Sadeq, B., \& Orhan, E. (2019). Investigation of the Exercise Dependence of Athletes Doing Kickboxing, Taekwondo and Muaythai. Sports. https://doi.org/10.20944/preprints201901.0233.v1

Peachey, J. W., Damon, Z. J., Zhou, Y., \& Burton, L. J. (2015). Forty years of leadership research in sport management: A review, synthesis, and conceptual framework. Journal of Sport Management. https://doi.org/10.1123/jsm.2014-0126

Phanpheng, Y., Larha, W., \& Hirantrakul, A. (2020). Effects Of Wai Khru Muaythai Training To Balance Ability In The Elderly. Sport Scientific \& Practical Aspects.

Phosawat Saengsawang, Chairit Siladech, \& Prapat Laxanaphisuth. (2015). The History and Development of Muaythai Boran. Journal of Sports Science. https://doi.org/10.17265/2332-7839/2015.03.007

Ransdell, L. B., \& Murray, T. (2016). Functional Movement Screening. Strength and Conditioning Journal. https://doi.org/10.1519/ssc.0000000000000209

Severi, K. E., Portugues, R., Marques, J. C., O'Malley, D. M., Orger, M. B., \& Engert, F. (2014). Neural Control and Modulation of Swimming Speed in the Larval Zebrafish. Neuron. https://doi.org/10.1016/j.neuron.2014.06.032

Statton, M. A., Encarnacion, M., Celnik, P., \& Bastian, A. J. (2015). A single bout of moderate aerobic exercise improves motor skill acquisition. PLoS ONE. https://doi.org/10.1371/journal.pone. 0141393

Syarifoeddin, E. W. (2018). The Effect of Plyometric Exercise using Continual, Interval, and Muscle Power Methods towards Push Kick Frequency on Muaythai Altheles in Mataram, West Nusa Tenggara. Researchers World : Journal of Arts, Science and Commerce. https://doi.org/10.18843/rwjasc/v9i4/14

Volek, J. S., Noakes, T., \& Phinney, S. D. (2015). Rethinking fat as a fuel for endurance exercise. European Journal of Sport Science. https://doi.org/10.1080/17461391.2014.959564

Voss, M. W., Weng, T. B., Burzynska, A. Z., Wong, C. N., Cooke, G. E., Clark, R., ... Kramer, A. F. (2016). Fitness, but not physical activity, is related to functional integrity of brain networks associated with aging. Neurolmage. https://doi.org/10.1016/j.neuroimage.2015.10.044

Wang, L., Talwar, V., Osakada, T., Kuang, A., Guo, Z., Yamaguchi, T., \& Lin, D. (2019). Hypothalamic Control of Conspecific Self-Defense. Cell Reports. https://doi.org/10.1016/j.celrep.2019.01.078 